AIms: Annexin I (ANXA1), a $37 \mathrm{kDa}$ member of the annexin family of $\mathrm{Ca}^{2+}$-binding and phospholipidbinding proteins, is particularly abundant in various populations of peripheral blood leukocytes. Since this protein modulates the anti-inflammatory actions of the steroid hormones, the purpose of this study was to investigate the effects of the female sex steroid hormone, $17 \beta$-estradiol $\left(E_{2} \beta\right)$, on the synthesis and secretion of ANXA1 in the human CCRF-CEM acute lymphoblastic leukemia cell line.

Methods: Complementary reverse transcription-polymerase chain reaction and Western blot assays were performed to study the effect of $E_{2} \beta$ on the expression of mRNA and protein ANXA1, respectively.

Results and discussion: Treatment of CCRF-CEM cells with $E_{2} \beta$, for $30 \mathrm{~min}$, stimulated the synthesis of ANXA1 mRNA molecules, and increased the cellular level of ANXA1 protein. Moreover, when the cells were incubated with $E_{2} \beta$, under the same experimental conditions, a significant increase in the amount of ANXA1 secreted from the cells was also detected. ICI 182,780 , a selective inhibitor of the intracellular estrogen receptor, had no effect on the $E_{2} \beta$-stimulated expression and externalisation of ANXA1. Taken together, these results indicate that $E_{2} \beta$ induces de novo synthesis of ANXA1 and stimulates its secretion in the CCRF-CEM cell line, apparently through a mechanism independent of the intracellular estrogen receptor.

Key words: Annexin I, 17 $\beta$-Estradiol, Lymphoblastic cell line, ICI 182,780

\section{$17 \beta$-Estradiol promotes the synthesis and the secretion of annexin I in the CCRF-CEM human cell line}

Margarida Castro-Caldas ${ }^{1}$, Carlos B. Duarte ${ }^{1}$, Arsélio P. Carvalho ${ }^{1}$ and M. Celeste Lopes ${ }^{1,2, C A}$

${ }^{1}$ Center for Neuroscience of Coimbra, Department of Zoology, University of Coimbra, 3004-517 Coimbra, Portugal, and ${ }^{2}$ Faculty of Pharmacy, University of Coimbra, Coimbra, Portugal

\footnotetext{
${ }^{\mathrm{CA}}$ Corresponding Author

Tel: $(+351) 239480236$

Fax: (+351) 239480217

E-mail: mcflopes@imagem.ibili.uc.pt
}

\section{Introduction}

Annexin I (ANXA1) belongs to the annexin family of $\mathrm{Ca}^{2+}$-binding and phospholipid-binding proteins that lack the classic 'EF-hand' motif for $\mathrm{Ca}^{2+}$ binding. ${ }^{1} \mathrm{~A}$ growing body of evidence indicates that ANXA1 acts as an endogenous anti-inflammatory mediator. ANXA1 has been implicated in several biological processes, including cell growth and differentiation, inhibition of chemotaxis, and release of inflammatory mediators, such as eicosanoids ${ }^{2,3}$ and inflammatory cytokines. ${ }^{4}$

Human monocytes and polymorphonuclear neutrophils constitutively express the protein ANXA1, ${ }^{1,5}$ as well as plasma membrane, specific and $\mathrm{Ca}^{2+}$. dependent binding sites for this protein. ${ }^{1,2}$ In contrast to what has been described for those cells, little is known about the capacity of lymphocytes to synthesise and secrete ANXA1. ${ }^{6-8}$ Interestingly, the steroid hormone $17 \beta$-estradiol $\left(E_{2} \beta\right)$ has been reported to have anti-inflammatory properties, which result, at least in part, from a direct action of the hormone on lymphocytes. ${ }^{9}$ Among lymphoid cells, T lymphocytes appear to be the most sensitive to the effects of $E_{2} \beta .^{10,11}$ Furthermore, some of the antiinflammatory effects of $E_{2} \beta$ are identical to those exerted by ANXA1. ${ }^{12,13}$ However, the ability of $E_{2} \beta$ to induce ANXA1 synthesis either in lymphocytes or other cell types has not been reported to date. Therefore, the objective of this study was to investigate the synthesis and secretion of ANXA1 in lymphocytes, in response to $E_{2} \beta$. For this purpose, we used the human acute lymphoblastic leukaemia cell line CCRF-CEM, which expresses characteristics of T lymphocytes. ${ }^{14}$

\section{Materials and methods}

\section{Chemicals}

Mouse monoclonal antibodies against ANXA1 and actin were purchased, respectively, from BAbCO (CA, USA) and Boehringer Mannheim (Carnaxide, Portugal), and the horseradish peroxidase-conjugated goat anti-mouse immunoglobulin was from Pierce (IL, USA). ICI 182,780 was kindly supplied by AstraZeneca Biociência (Barcarena, Portugal). All other reagents were from Sigma Chemical Co. 


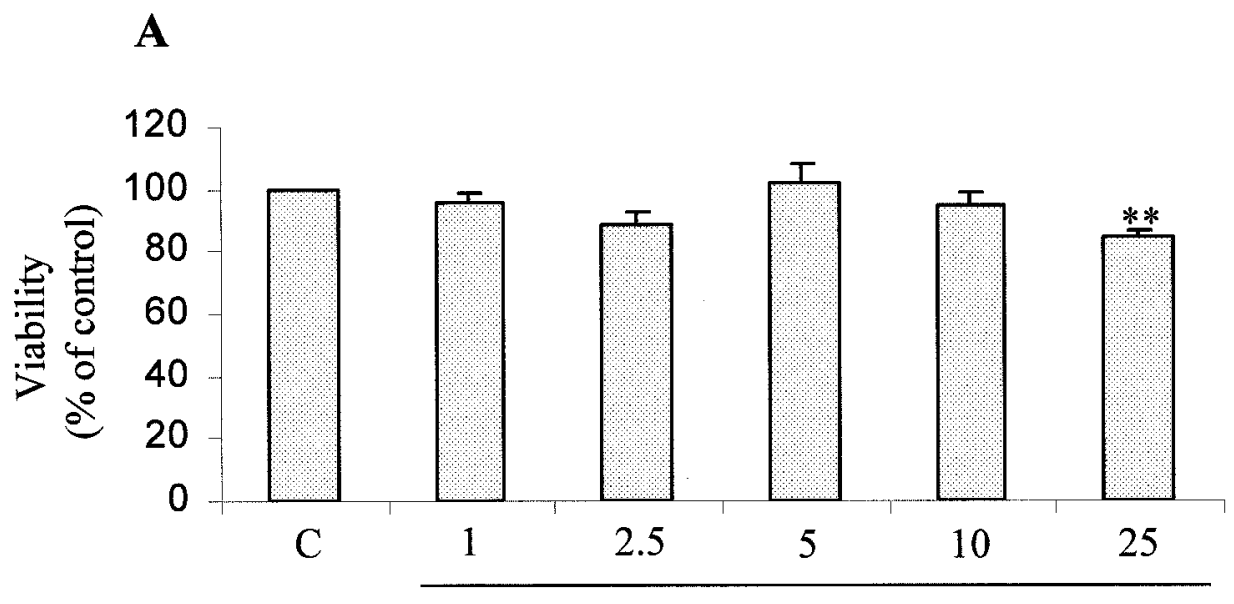

ICI $182,780(\mu \mathrm{M})$

B

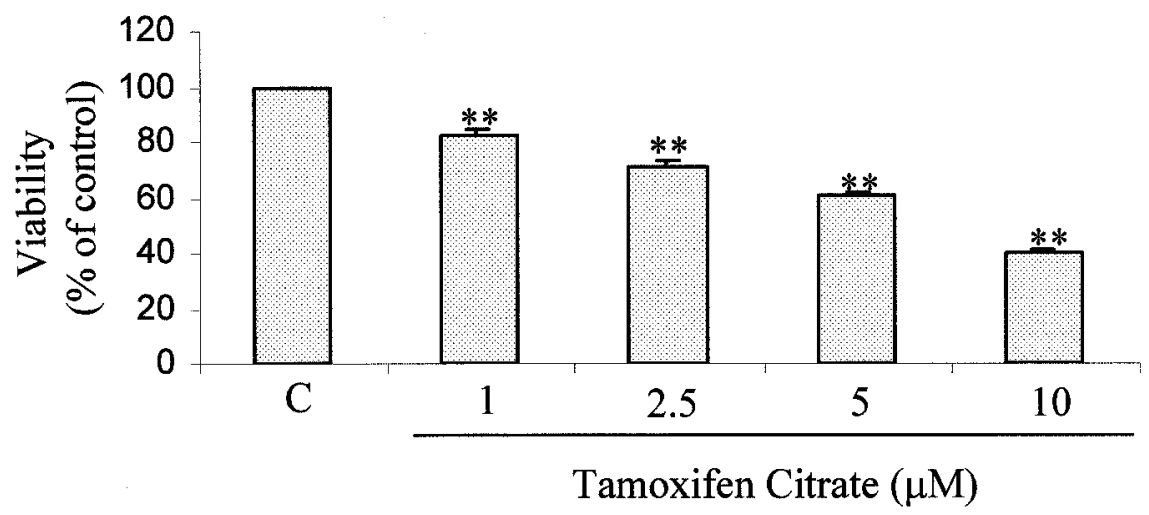

FIG. 1. Cell viability of CCRF-CEM cells when incubated in the presence of estrogen antagonists. Cells were incubated in the absence (control, C) or in the presence of ICI 182,780 (1-25 $\mathrm{M})(\mathrm{A})$, or with tamoxifen citrate $(1-10 \mu \mathrm{M})(\mathrm{B})$. Cell viability was assessed by the MTT reduction test. The data shown are an average of three independent experiments. Values are mean \pm SD, ** $p<0.01$ as determined by one-way ANOVA with Dunnett's post test.

\section{Cell culture}

The human T-cell CCRF-CEM acute lymphoblastic leukemia cell line (ATCC, Rockville, MD, USA) was maintained in RPMI medium supplemented with $10 \%$ fetal calf serum (FCS), $100 \mu \mathrm{g} / \mathrm{ml}$ of streptomycin and $100 \mathrm{U} / \mathrm{ml}$ of penicillin, at $37^{\circ} \mathrm{C}$, in an atmosphere of $5 \% \mathrm{CO}_{2} / 95 \%$ air. CCRF-CEM cells $\left(1 \times 10^{6}\right.$ cells $\left./ \mathrm{ml}\right)$ were plated in six-well culture dishes with RPMI supplemented with $2.5 \%$ FCS and antibiotics, for $14 \mathrm{~h}$ prior to all the experiments described.

\section{Cell viability}

Viability of the CCRF-CEM cells was always checked by the trypan blue exclusion and MTT reduction tests prior to the experiments. Assessment of MTT reduction was made by the colorimetric assay, using 3-(4,5-dimethylthiazol-2yl)-2,5-diphenyl tetrazolium bromide (MTT), as previously described. ${ }^{15}$

\section{Reverse transcription-polymerase chain reaction assays}

For the reverse transcription-polymerase chain reaction (RT-PCR) assays, CCRF-CEM cells were incubated in the presence of or in the absence of $E_{2} \beta$ (0.01-1 $\mu \mathrm{M})$, or in $\mathrm{E}_{2} \beta(1 \mu \mathrm{M})+$ the estrogen antagonist ICI $182,780(10 \mu \mathrm{M})$, for $30 \mathrm{~min}-4 \mathrm{~h}$. After incubation, the cells were washed twice in phosphate-buffered saline (PBS) with $0.1 \%$ diethyl pyrocarbonate, and the total RNA was isolated with TRIzol. RT-PCR was standardised by amplifying a 410 base pair (bp) sequence of ANXA1 mRNA with the primers 5'CAAACTGTGAAGTCATC-

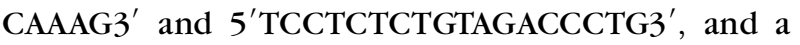
$540 \mathrm{bp}$ sequence of the $\beta$-actin mRNA (as an internal control) with the primers 5'GTGGGGCGCCCCAGGCACCA3' and 5'CTCCTTAATGTCACGCACGATTTC 3 '. The reactions were performed with Ready-to-go RTPCR beads using $150 \mathrm{ng}$ of total RNA and the 
following program: $42^{\circ} \mathrm{C}$ for $30 \mathrm{~min}, 95^{\circ} \mathrm{C}$ for $5 \mathrm{~min}$, 20 cycles $\left(95^{\circ} \mathrm{C}\right.$ for $1 \mathrm{~min}, 55^{\circ} \mathrm{C}$ for $1 \mathrm{~min}, 72^{\circ} \mathrm{C}$ for $1 \mathrm{~min}$ ), and $72^{\circ} \mathrm{C}$ for $5 \mathrm{~min}$. The RT-PCR products were separated in a 1\% agarose gel electrophoresis, and visualised by ethidium bromide staining.

\section{Western blot analysis}

For immunodetection of ANXA1, CCRF-CEM cells were incubated with or without $\mathrm{E}_{2} \beta$ (0.01-1 $\left.\mu \mathrm{M}\right)$, or with $\mathrm{E}_{2} \beta(1 \mu \mathrm{M})+$ ICI $182,780(10 \mu \mathrm{M})$, for $30 \mathrm{~min}-4 \mathrm{~h}$. After incubation, the cells were washed by centrifugation in PBS. The secreted ANXA1 bound to plasma membrane receptors was extracted by washing the cells, for $10 \mathrm{sec}$, in $1 \mathrm{mM}$ of ethylenediaminetetraacetic acid (EDTA), as previously described. ${ }^{16}$ The supernatant was collected for secreted plasma membrane-bound ANXA1 detection, and the pelleted cells were washed once again in PBS to remove all secreted protein contaminant. Cells were then lysed in lysis buffer $(10 \mathrm{mM}$ of Tris-HCl (pH 7.6), 10\% glycerol, $5 \mathrm{mM}$ of $\beta$-mercaptoethanol, and the protease inhibitor cocktail) and sonicated. Samples of cellular lysates $(30 \mu \mathrm{g})$ and the cell supernatant containing the secreted proteins $(2 \mu \mathrm{g})$ were added $(1: 1)$ to denaturating buffer $(200 \mathrm{mM}$ of Tris, $200 \mathrm{mM}$ of bicine, $8 \mathrm{M}$ of urea, $4 \%$ sodium dodecyl sulfate (SDS), $10 \% \beta$-mercaptoethanol and $0.2 \%$ bromophenol blue), and subjected to $12 \%$ SDS-polyacrylamide gel electrophoresis. After electrotransferration to a PVDF membrane, ANXA1 was detected by incubation with a mouse anti-ANXA1 monoclonal antibody $(2 \mu \mathrm{g} / \mathrm{ml})$, followed by incubation with a horseradish peroxidase-conjugated goat anti-mouse antibody. The immunocomplexes were visualised by the enhanced chemiluminescence (ECL) method. To demonstrate equivalent total protein loading, the stripping of the membrane was performed with stripping buffer (100 $\mathrm{mM}$ of $\beta$-mercaptoethanol, 2\% SDS, $62.5 \mathrm{mM}$ of Tris- $\mathrm{HCl}(\mathrm{pH} 6.7)$ at $55^{\circ} \mathrm{C}$, and the membrane was treated as already indicated using the anti-actin mouse monoclonal antibody $(0.1 \mu \mathrm{g} / \mathrm{ml})$. The Ponceau $S$ staining of the PVDF membrane was used to show equivalent secreted protein loading.

\section{Statistical analysis}

Assay data were expressed as mean \pm SD. Comparison of data from two treatment groups was made by the Student's two-tailed unpaired $t$-test. When comparison of data from more than two treatment groups was required, one-way analysis of variance (ANOVA) with Dunnett's post test was used. A probability of less than $5 \%$ (i.e. $p<0.05$ ) was taken as statistically significant.
$\mathbf{A}$

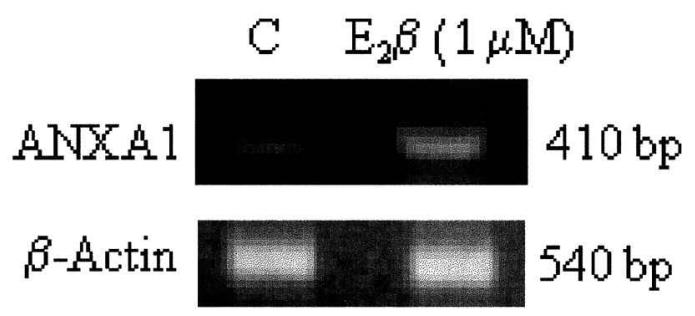

B

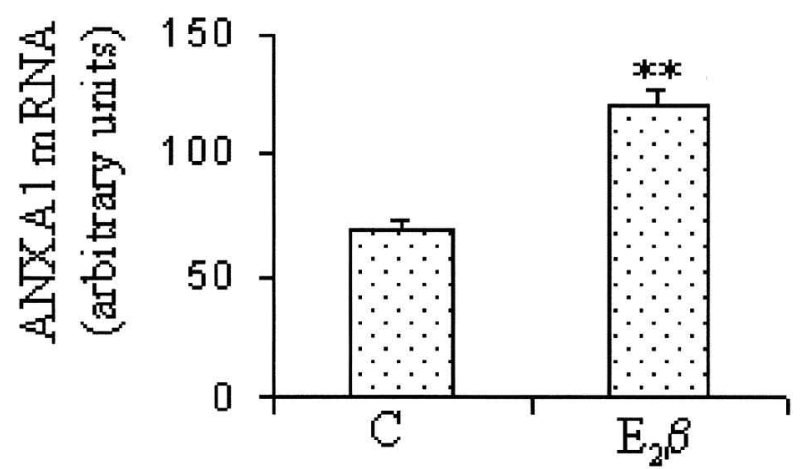

FIG. 2. Effect of E2 $\beta$ on ANXA1 mRNA synthesis in CCRFCEM cells. Cells were incubated in the absence (control, $C$ ) and in the presence of $E_{2} \beta(1 \mu \mathrm{M})$ for $30 \mathrm{~min}(\mathrm{~A})$. The bands were quantified with an image analyser (B). ANXA1 mRNA was detected by RT-PCR with a pair of primers specific for a fragment of ANXA1 mRNA. The data shown are an average of three independent experiments. Values are mean $\pm S D, * *$ $p<0.01$ as determined by Student's two-tailed unpaired $t$-test.

\section{Results}

\section{Cell viability}

The cell viability was previously assessed prior to each the experiment. The viability of CCRF-CEM cells incubated in the presence of $\mathrm{E}_{2} \beta$ was always >95\% (data not shown). When the cells were incubated with the pure anti-estrogen ICI 182,780 at the concentrations used in the present work $(10 \mu \mathrm{M})$, the viability was also $>95 \%$. Concentrations higher than $10 \mu \mathrm{M}$ of ICI 182,780 caused cell death (Fig. 1A). The estrogen antagonist tamoxifen citrate, at the concentration of $1 \mu \mathrm{M}$, decreased cell viability by more than 18\% (Fig. 1B). Therefore, tamoxifen citrate was not used in the present work.

\section{Effect of $E_{2} \beta$ on ANXA1 mRNA synthesis in CCRF-CEM cells}

The ability of $E_{2} \beta$ to induce ANXA1 mRNA synthesis in CCRF-CEM cells was studied by RT-PCR, using a specific pair of primers that amplify a $410 \mathrm{bp}$ sequence of ANXA1 mRNA (Fig. 2). 
A

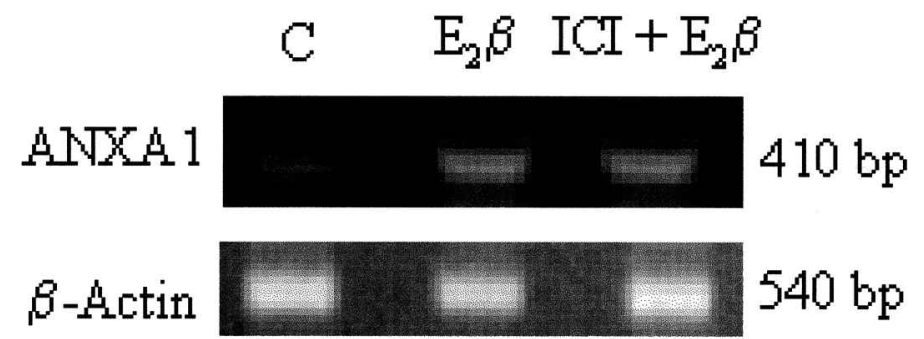

B

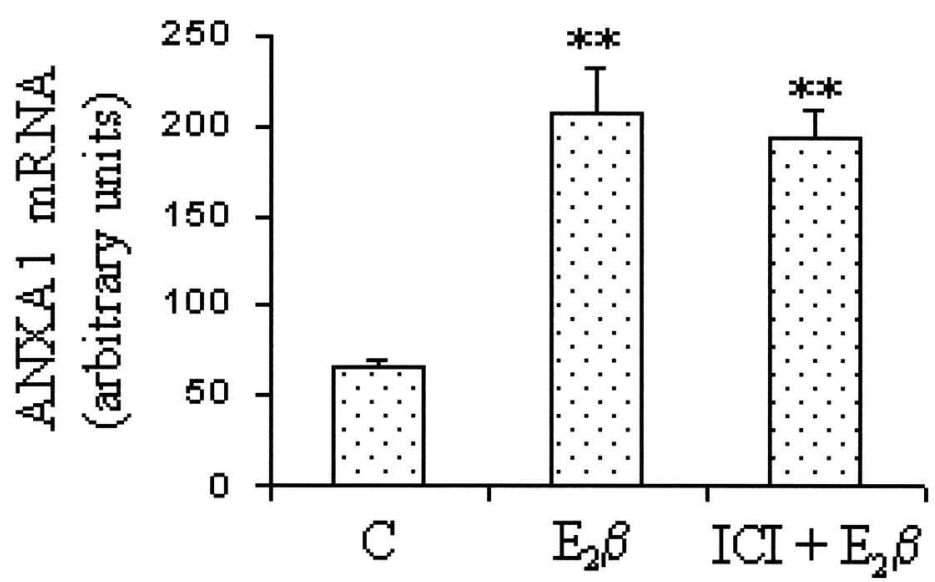

FIG. 3. Effect of E2 $\beta$ and ICI 182,780 on ANXA1 mRNA synthesis in CCRF-CEM cells. Cells were incubated in the absence (control, C) and in the presence of $E_{2} \beta(1 \mu \mathrm{M})$, and in $\mathrm{E} 2 \beta(1 \mu \mathrm{M})+\mathrm{ICl} 182,780(10 \mu \mathrm{M})$ for $30 \mathrm{~min}(\mathrm{~A})$. The bands were quantified with an image analyser (B). ANXA1 mRNA was detected by RT-PCR with a pair of primers specific for a fragment of ANXA1 mRNA. The data shown are an average of three independent experiments. Values are mean $\pm \mathrm{SD},{ }^{*} p<0.01$ as determined by one-way ANOVA with Dunnett's post test.

CCRF-CEM cells incubated in the presence of $\mathrm{E}_{2} \beta$ at a concentration ranging from 0.01 to $1 \mu \mathrm{M}$, for 30 min, showed an increase in ANXA1 mRNA expression (data not shown). However, the increase was constant and reached statistical significance only when the cells were treated with $1 \mu \mathrm{M}$ of $\mathrm{E}_{2} \beta$ (120.2 \pm 6.7 arbitrary units $(\mathrm{AU})$ versus $69.6 \pm 2.6 \mathrm{AU}$, in control; $p<0.01$ ) (Fig. 2). Longer incubation in the presence of $\mathrm{E}_{2} \beta$ did not change these results (data not shown).

Co-incubation of CCRF-CEM cells with $\mathrm{E}_{2} \beta(1 \mu \mathrm{M})$ and the estrogen antagonist ICI 182,780 $(10 \mu \mathrm{M})$ was performed to investigate the role of the estrogen receptor (ER) in the effect of $E_{2} \beta$ on the ANXA1 mRNA expression (Fig. 3). The rise in the ANXA1 mRNA level induced by $\mathrm{E}_{2} \beta(1 \mu \mathrm{M})$, in the presence or in the absence of ICI $182,780(10 \mu \mathrm{M})$ was not significantly different $(p>0.05)$. However, confirming the previous results, both $\mathrm{E}_{2} \beta(1 \mu \mathrm{M})(207.7 \pm$ $25.2 \mathrm{AU})$ and $\mathrm{E}_{2} \beta(1 \mu \mathrm{M})+$ ICI $182,780(10 \mu \mathrm{M})$ $(194.1 \pm 14.1 \mathrm{AU})$ induced a significant increase of the control level of ANXA1 mRNA $(74.25 \pm 2.2 \mathrm{AU})(p<$ 0.01) (Fig. 3B).

Effect of $E_{2} \beta$ on ANXA1 protein expression and secretion in CCRF-CEM cells

To test the effect of $E_{2} \beta$ on ANXA1 protein synthesis and secretion, CCRF-CEM cells were incubated in the presence or in the absence of different concentrations of $E_{2} \beta(0.01-1 \mu \mathrm{M})$. A significant, measurable and constant effect was only observed with $1 \mu \mathrm{M}$ of $\mathrm{E}_{2} \beta$ (data not shown). As a consequence, $1 \mu \mathrm{M}$ of $\mathrm{E}_{2} \beta$ was the concentration used in all the experiments performed to study ANXA1 protein expression and secretion.

As shown in Fig. 4, the basal level of cellular ANXA1 was significantly decreased after $30 \mathrm{~min}$ $(359.1 \pm 16.1 \mathrm{AU})$ of incubation with $\mathrm{E}_{2} \beta$ relative to control untreated cells $(488.8 \pm 33.6 \mathrm{AU} ; p<0.01)$. After $2 \mathrm{~h}(518.9 \pm 35.1 \mathrm{AU})$ and $4 \mathrm{~h}(568.2 \pm$ 13.8 AU) of incubation with $\mathrm{E}_{2} \beta$, the cellular con- 

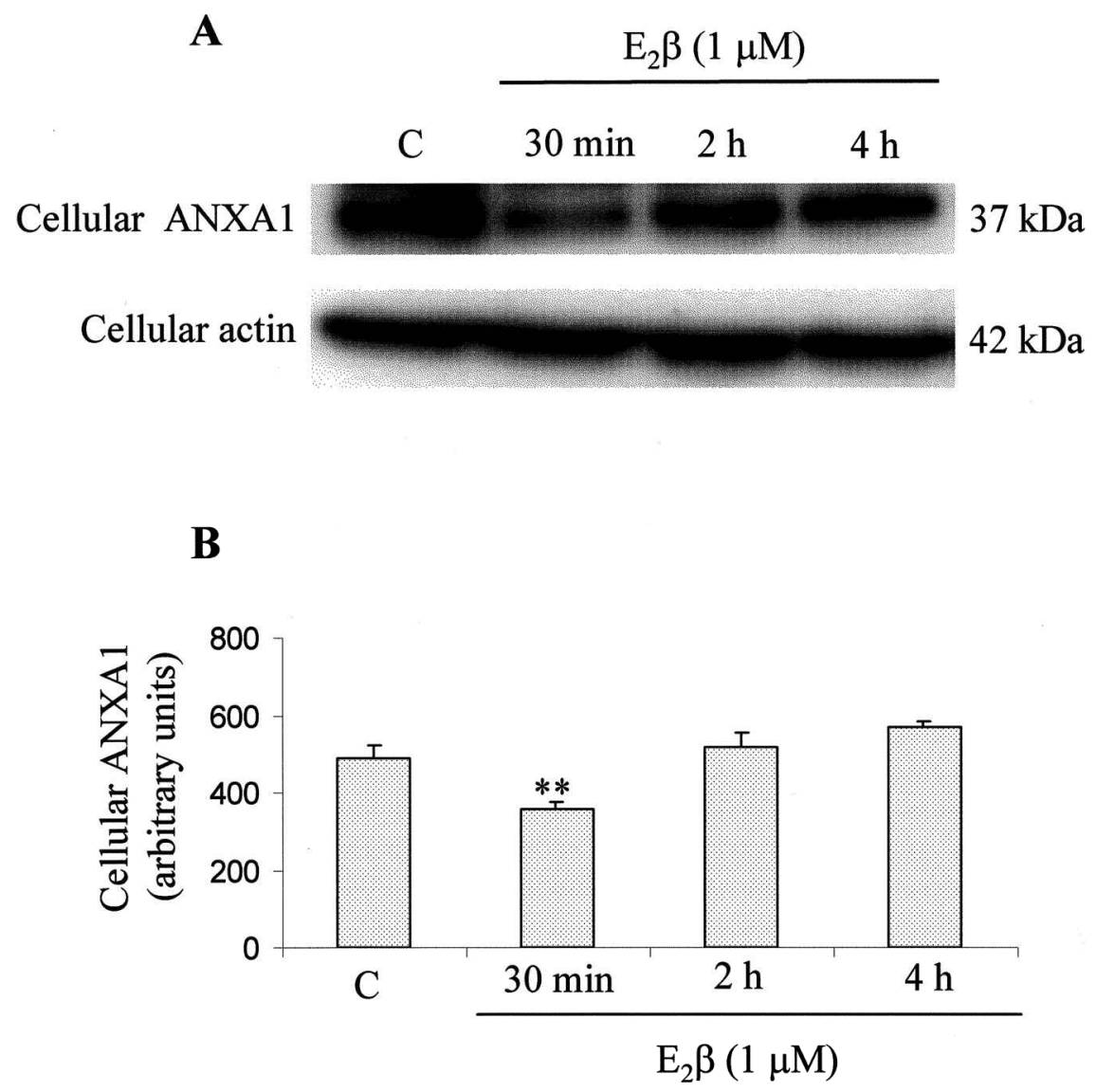

FIG. 4. Effect of E2 $\beta$ on cellular ANXA1 protein expression in CCRF-CEM cells. Cells were incubated in the absence (control, C) or in the presence of $E_{2} \beta(1 \mu \mathrm{M})$, for $30 \mathrm{~min}, 2 \mathrm{~h}$ and $4 \mathrm{~h}$. The cellular content of ANXA1 was determined by Western blot analysis (A), and the bands were quantified with an image analyser (B). Detection of cellular ANXA1 protein was achieved using a mouse monoclonal anti-ANXA1 antibody. The data shown are an average of three independent experiments. Values are mean $\pm \mathrm{SD},{ }^{*} p<0.01$ as determined by one-way ANOVA with Dunnett's post test.

tent of the protein was increased, reaching levels statistically equivalent to the control $(488.8 \pm$ $33.6 \mathrm{AU} ; p>0.05)$. Since cell viability was well maintained throughout the experiments (data not shown), the loss in cellular ANXA1 after $30 \mathrm{~min}$ of exposure to $E_{2} \beta$ is certainly due to the specific secretion of the protein. In fact, the level of the plasma membrane-bound EDTA-extractable ANXA1 increased from $184.1 \pm 29.2 \mathrm{AU}$ (control) to $378.8 \pm$ $29.9,584.3 \pm 79.3$ and $607.3 \pm 47.1 \mathrm{AU}$ in cells treated with $\mathrm{E}_{2} \beta$ for $30 \mathrm{~min}, 2 \mathrm{~h}$ and $4 \mathrm{~h}$, respectively $(p<0.05, p<0.01$ and $p<0.01$ ) (Fig. 5). Taken together, these results indicate that $\mathrm{E}_{2} \beta$ induces de novo synthesis of ANXA1 and stimulates its secretion in CCRF-CEM cells.

Co-incubation of CCRF-CEM cells with $\mathrm{E}_{2} \beta(1 \mu \mathrm{M})$ and the estrogen antagonist ICI $182,780(10 \mu \mathrm{M})$ was performed to investigate the role of the ER in the effect of $E_{2} \beta$ on the synthesis and secretion of ANXA1. ICI 182,780 neither affected the amount of plasma membrane-bound ANXA1 in control cells or reversed the $E_{2} \beta$-dependent secretion of ANXA1 in CCRF-CEM cells (data not shown).

\section{Discussion}

Several studies reported in the literature have shown that glucocorticoid hormones have a remarkable effect on ANXA1 protein expression and secretion in a variety of in vivo and in vitro systems. ${ }^{1,4,5}$ But, to our knowledge, this is the first study demonstrating that the sex steroid hormone $\mathrm{E}_{2} \beta$ stimulates the synthesis and the secretion of ANXA1.

Incubating the lymphoblastic CCRF-CEM cells with $\mathrm{E}_{2} \beta(1 \mu \mathrm{M})$ for $30 \mathrm{~min}$ resulted in an increased expression of ANXA1 mRNA (Fig. 2). When the cells were incubated with this hormone for $2 \mathrm{~h}$, the synthesis of ANXA1 mRNA molecules was followed by an increase in the cellular content of ANXA1 protein (Fig. 4). Moreover, treatment of CCRF-CEM cells with $\mathrm{E}_{2} \beta(1 \mu \mathrm{M})$ for $30 \mathrm{~min}$ caused a significant increase in the amount of ANXA1 bound to specific ANXA1 binding receptors localised in the outer surface of the plasma membrane of these cells (Fig. 5). These results are in agreement with those published by Philip et $a l .{ }^{16}$ They reported that washing the cells in a $\mathrm{Ca}^{2+}$ free medium removes the ANXA1 from the outer 


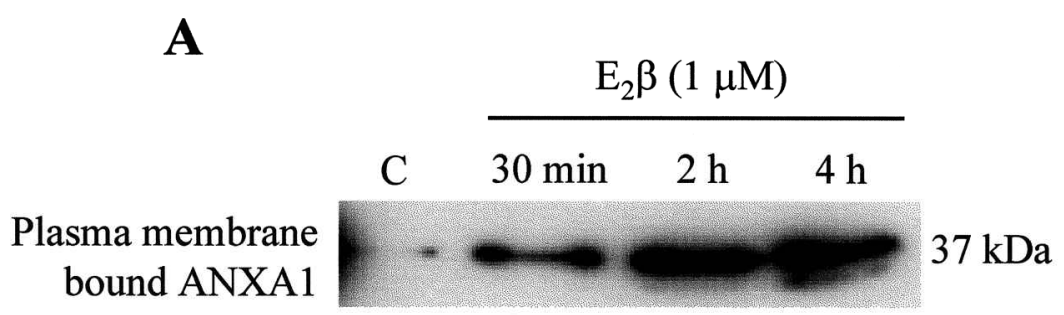

B

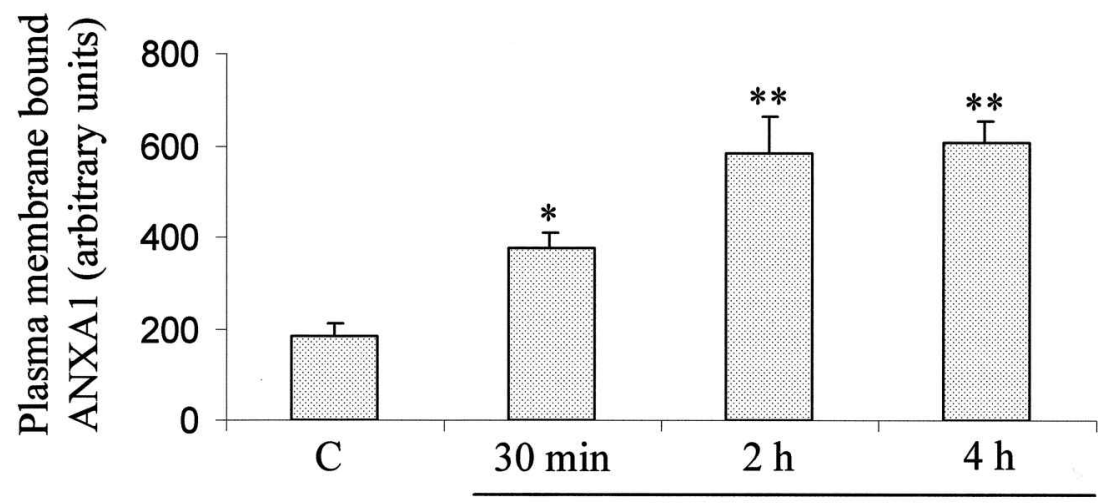

$\mathrm{E}_{2} \beta(1 \mu \mathrm{M})$

FIG. 5. Effect of E2 $\beta$ on ANXA1 secretion in CCRF-CEM cells. Cells were incubated in the absence (control, C) or in the presence of $E_{2} \beta(1 \mu \mathrm{M})$ for $30 \mathrm{~min}, 2 \mathrm{~h}$ and $4 \mathrm{~h}(\mathrm{~A})$. The bands were quantified with an image analyser (B). Plasma membrane bound ANXA1 was obtained after washing the cells with $1 \mathrm{mM}$ EDTA buffer, as described in 'Materials and methods'. Detection of plasma membrane bound ANXA1 was achieved using a mouse monoclonal anti-ANXA1 antibody. The data shown are an average of three independent experiments. values are mean $\pm \mathrm{SD},{ }^{*} p<0.05$ and ${ }^{*} p<0.01$ as determined by one-way ANOVA with Dunnett's post test.

surface of the plasma membrane of the cells, and that this protein corresponds to the externalised ANXA1. Based on these findings, our results indicate that $\mathrm{E}_{2} \beta$ efficiently stimulates ANXA1 secretion.

The mechanisms by which $\mathrm{E}_{2} \beta$ stimulates the synthesis and the secretion of ANXA1 are still unknown. It is known that $\mathrm{E}_{2} \beta$ exerts its major effects on cell growth, differentiation and function by specifically interacting with intracellular ER. ${ }^{17}$ The complex $E_{2} \beta$-ER migrates to the nucleus of the cells, where it binds to estrogen-responsive elements present in the genomic DNA. The anti-estrogens compete with the hormone $\left(E_{2} \beta\right)$ for the estrogen receptor, giving rise to inactive ligand-receptor complexes. ${ }^{18}$ For example, ICI 182,780 binds with high affinity to intracellular ER, inhibiting its dimerisation, and functions as a pure $E_{2} \beta$ antagonist. ${ }^{19,20}$

In this work, we used ICI $182,780(10 \mu \mathrm{M})$ to investigate the involvement of the intracellular ER on ANXA1 expression and secretion induced by $\mathrm{E}_{2} \beta$ $(1 \mu \mathrm{M})$. Our results show that ICI 182,780 did not inhibit the $E_{2} \beta$-induced stimulation of ANXA1 mRNA expression (Fig. 3). We also observed that ICI 182,780 was without effect on the synthesis and secretion of ANXA1 protein induced by $E_{2} \beta$ (data not shown).
Taken together, these results suggest that the intracellular ERs are probably not involved in mediating the $E_{2} \beta$ effects reported here. Receptor-independent mechanisms have been suggested to mediate the response of estrogen in different cell types, in a manner dependent on the culture conditions and estrogen concentrations. ${ }^{21}$ Nanomolar concentrations of estrogen seem to exert their effects by a direct genomic action of the complex estrogen-ER on DNA, activating specific estrogen-responsive genes, ${ }^{17}$ whereas micromolar concentrations of this hormone appear to also activate other intracellular signaling pathways, like the mitogen-activated protein kinase cascade. ${ }^{21-23}$ It is worth noticing that, in our study, the concentrations of $E_{2} \beta$ that reproducibly induced ANXA1 expression and secretion are in the micromolar range, thus further supporting that the $\mathrm{E}_{2} \beta$ effects observed are independent of the ER. Nevertheless, it could be argued that other ER antagonists, such as tamoxifen citrate, as well as higher concentrations of ICI 182,780 should be used to fully characterise the involvement of ER in the $\mathrm{E}_{2} \beta$-induced responses. Unfortunately, we found that tamoxifen citrate and ICI 182,780 are toxic to CCRF-CEM cells in concentrations higher than 1 and $10 \mu \mathrm{M}$, respectively 
(Fig. 1), which precluded the performance of those studies. Thus, we cannot fully exclude the involvement of the ER in mediating $\mathrm{E}_{2} \beta$-induced ANXA1 expression and secretion, although it seems highly unlikely.

In summary, the synthesis and secretion of ANXA1 in CCRF-CEM cells in response to $\mathrm{E}_{2} \beta(1 \mu \mathrm{M})$ is consistent with in vivo studies showing that $\mathrm{E}_{2} \beta$ in physiological concentrations $(1 \mathrm{pM}-100 \mu \mathrm{M})$ participates in the regulation of anti-inflammatory events. ${ }^{9,24,25}$ Although the results from our studies suggest that $\mathrm{E}_{2} \beta$ acts by an ER-independent pathway, further studies are being performed to better understand the mechanisms by which this hormone regulates the expression of ANXA1 in the lymphoid lineage.

ACKNOWLEDGEMENTS. This work was supported by the Portuguese Foundation for Science and Technology (F.C.T.). M. Castro-Caldas is sponsored by a PRAXIS XXI MSc. fellowship (BM/19156/99).

\section{References}

1. Goulding NJ, Guyre PM. Regulation of inflammation by lipocortin 1 . Immunol Today 1992; 13: 295-297.

2. Goulding NJ, Jefferiss CM, Pan L, Rigby WFC, Guyre PM. Specific binding of lipocortin-1 (annexin I) to monocytes and neutrophils is decreased in rheumatoid arthritis. Arthritis Rbeum 1992; 35: 1395-1397.

3. Goulding NJ, Euzger HS, Butt SK, Perretti M. Novel pathways for glucocorticoid effects on neutrophils in chronic inflammation. Inflamm Res 1998; 47: S158-S165.

4. Perretti M, Flower RJ. Measurement of lipocortin 1 levels in murine peripheral blood leukocytes by flow cytometry: modulation by glucocorticoids and inflammation. Br J Pharmacol 1996; 118: 605-610.

5. Buckingham JC, Flower RJ. Lipocortin 1: a second messenger of glucocorticoid action in the hypothalamo-pituitary-adrenocortical axis. Mol Med Today 1997; 3: 296-302.

6. Goulding NJ, Pan L, Wardwell K, Guyre VC, Guyre PM. Evidence for specific annexin I-binding proteins on human monocytes. Biochem $J$ 1996; 316: 593-597.

7. Perretti M, Flower RJ, Goulding NJ. The ability of murine leukocytes to bind lipocortin 1 is lost during acute inflammation. Biochem Biophys Res Commun 1993; 192: 345-350.

8. Kim HW, Choi E, Choi JR, Park YM, Lee SO, Moon HB, Na DS. Lipocortin 1 binding sites on human T-cells: the population of cells with binding sites is larger in CD8+ T-lymphocytes than in CD4+ T-lymphocytes. Biochem Mol Biol Int 1996; 40: 1167-1173.
9. Van den Brink HR, Wijk MJG, Bijlsma JWJ. Influence of steroid hormones on proliferation of peripheral blood mononuclear cells in patients with rheumatoid arthritis. Br J Rheumatol 1992; 31: 663-667.

10. Ahmed SA, Penhale WJ, Talal N. Sex hormones, immune responses, and autoimmune diseases. Mechanisms of sex hormone action. Am J Pathol 1985; 121: 531-551.

11. Salem ML, Matsuzaki G, Kichihara K, Madkour GA, Nomoto K. Betaestradiol suppresses $\mathrm{T}$ cell-mediated delayed-type hypersensitivity through suppression of antigen-presenting cell function and Th1 induction. Int Arch Allerg Immunol 2000; 121: 161-169.

12. Kassem M. Cellular and molecular effects of growth hormone and estrogen on human bone cells. APMIS 1997; 71: 1-30.

13. Stefano GB, Prevot V, Beauvillain JC et al. Estradiol coupling to human monocyte nitric oxide release is dependent on intracellular calcium transients: evidence for an estrogen surface receptor. J Immunol 1999; 163: 3758-3763.

14. Miranda L, Wolf J, Pichuantes S, Duke R. Isolation of the human PC6 gene encoding the putative host protease for HIV-1 gp160 processing in CD4+ T lymphocytes. Proc Natl Acad Sci USA 1996; 93: 7695-7700.

15. Mosman T. Rapid colorimetric assay for cellular growth and survival application to proliferation and cytotoxicity assays. J Immunol Methods 1983; 65: 55-63.

16. Philip JG, Flower RJ, Buckingham JC. Blockade of the classical pathway of protein secretion does not affect the cellular exportation of lipocortin1. Regulat Peptides 1998; 73: 133-139.

17. Benten WPM, Lieberherr M, Giese G, Wunderlich F. Estradiol binding to cell surface raises free calcium in $\mathrm{T}$ cells. FEBS Lett 1998; 422 349-353.

18. El-Tanani MKK, Green CD. Two separate mechanisms for ligandindependent activation of the estrogen receptor. Mol Endocrinol 1997; 11:928-937.

19. Sibonga JD, Dobnig H, Ryan M, RussellTT. Effect of high-affinity estrogen receptor ligand ICI 182,780 on the rat tibia. Endocrinology 1998; 139: 3736-3742.

20. Ferreira Mendes A, Caramona MM, Lopes MC. Changes in the subcellular distribution of the rat uterus oestrogen receptor as induced by oestradiol, tamoxifen and ZD 182,780. J Pbarmacol 1996; 48 $302-305$.

21. Endoh $\mathrm{H}$, Sasaki $\mathrm{H}$, Maruyama $\mathrm{K}$, Takeyama K-I, Waga I, Shimizu T, Kato $\mathrm{S}$, Kawashima H. Rapid activation of MAP kinase by estrogen in the bone cell line. Biochem Biophys Res Commun 1997; 235: 99-102.

22. Cutolo M, Sulli A, Seriolo B, Accardo S, Masi AT. Estrogens, the immune response and autoimmunity. Clin Exp Rbeumatol 1995; 13: 217-226.

23. Katzenellenbogen BS, Montano MM, Le Goff $\mathrm{P}$ et al. Antiestrogens: mechanisms and actions in target cells. J Steroid Biochem Mol Biol 1995 53: 387-393.

24. Li ZG, Danis VA, Brooks PM. Effect of gonadal steroids on the production of IL-1 and IL-6 by blood mononuclear cells in vitro. Clin Exp Rbeumatol 1993; 11: 157-162

25. Jansson L, Holmdahl R. Estrogen-mediated immunosuppression in autoimmune diseases. Inflamm Res 1998; 47: 290-301.

Received 25 June 2001;

Accepted 10 July 2001 


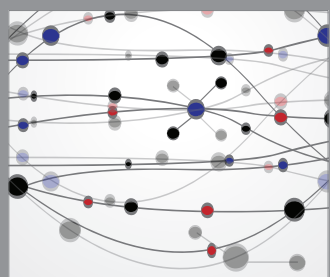

The Scientific World Journal
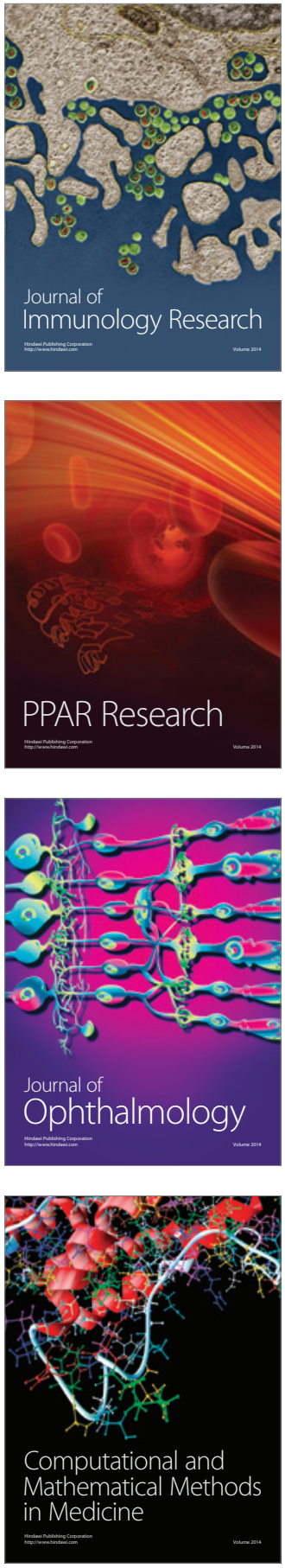

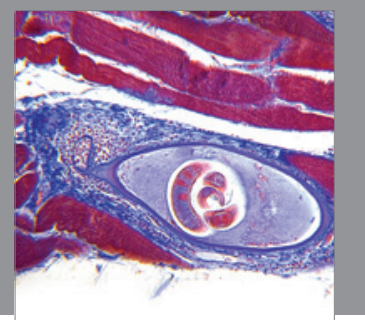

Gastroenterology

Research and Practice
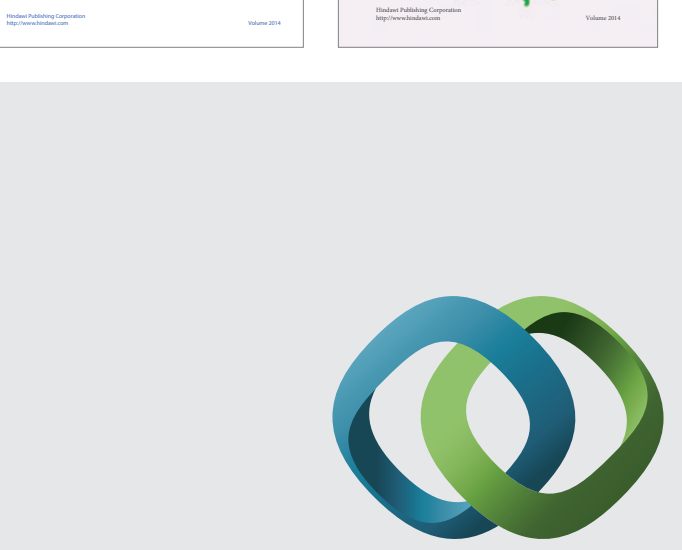

\section{Hindawi}

Submit your manuscripts at

http://www.hindawi.com
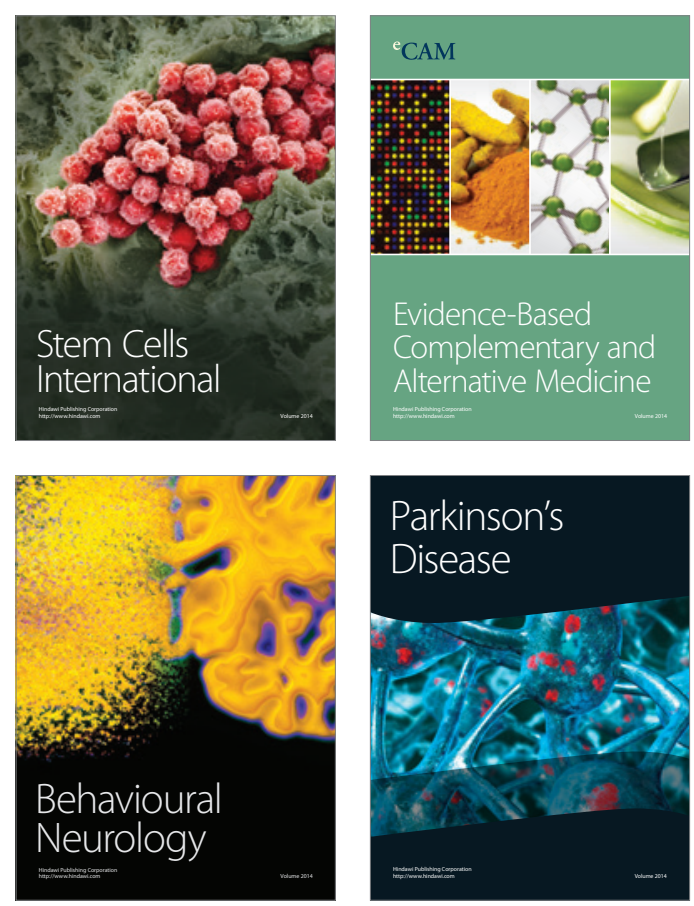

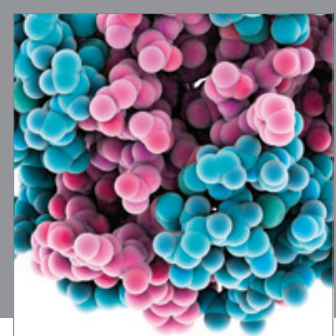

Journal of
Diabetes Research

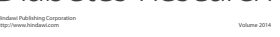

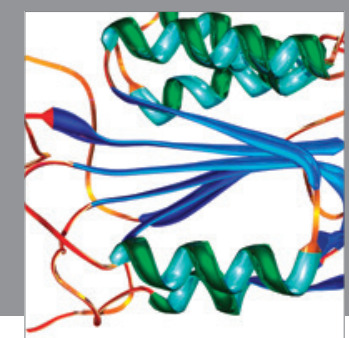

Disease Markers
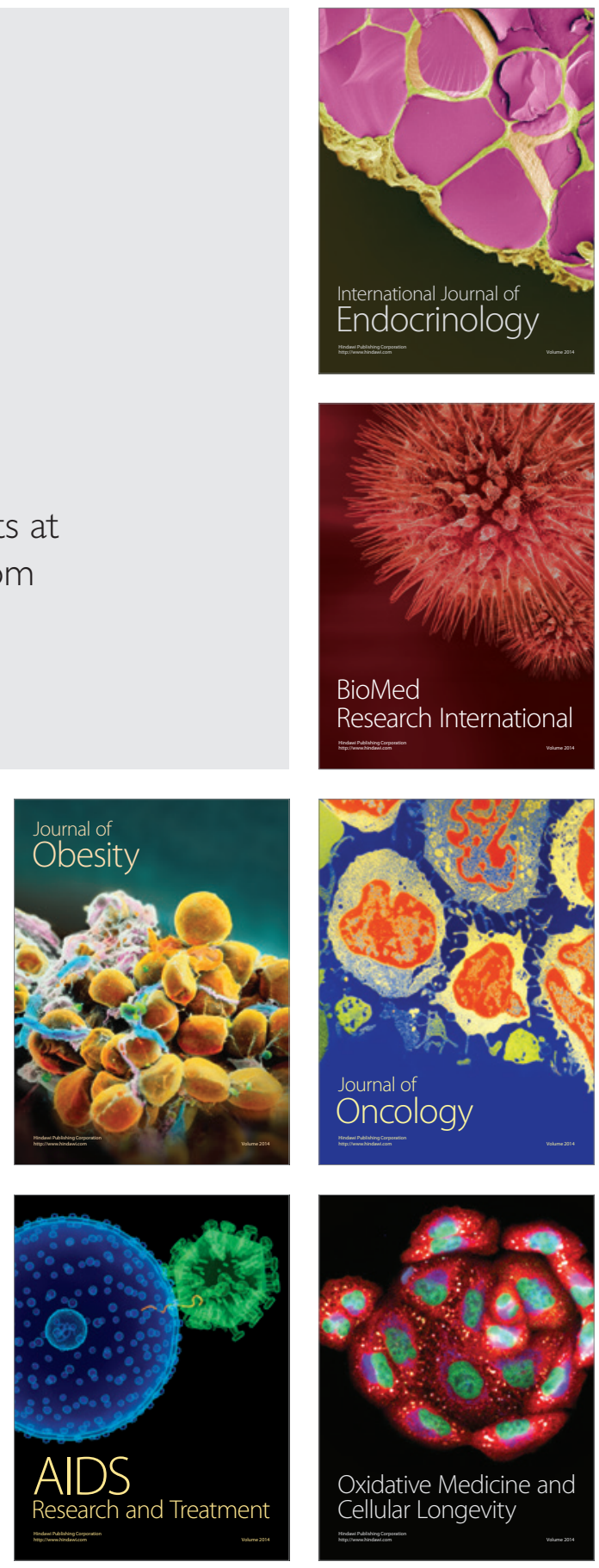